\title{
Saccharosporones A, B and C, cytotoxic antimalarial angucyclinones from Saccharopolyspora sp. BCC 21906
}

\author{
Chollaratt Boonlarppradab, Chanwit Suriyachadkun, Pranee Rachtawee and Wilunda Choowong \\ Three new angucyclinones, saccharosporones $A, B$ and $C$, together with $(+)$-ochromycinone, $(+)$-rubiginone $\mathbf{B}_{2}$, \\ tetrangulol methyl ether and fujianmycin $A$, were obtained from fermentation of the terrestrial actinomycete of the genus \\ Saccharopolyspora BCC 21906 isolated from a soil collected in Chanthaburi Province, Thailand. Structures of the new \\ compounds and their relative configurations were assigned by NMR spectral data interpretation. Saccharosporones A and B \\ exhibited antimalarial activity against Plasmodium falciparum K1 with $\mathrm{IC}_{50}$ values of 4.1 and $3.9 \mu \mathrm{m}$. Both metabolites also \\ possessed cytotoxic activities against cancer cell lines (KB, MCF-7 and $\mathrm{NCl}-\mathrm{H} 187$ ) and nonmalignant Vero cell, while \\ saccharosporone $\mathrm{C}$ only showed cytotoxic activity against $\mathrm{NCI}-\mathrm{H} 187$.
}

The Journal of Antibiotics (2013) 66, 305-309; doi:10.1038/ja.2013.16; published online 3 April 2013

Keywords: actinomycete; angucyclinone; antimalarial activity; cancer cell cytotoxicity; natural product; Saccharopolyspora sp.

\section{INTRODUCTION}

As angucycline metabolites are a large class of antibiotics with a broad spectrum of biological activities and interesting chemical structures, they have attracted much attention. ${ }^{1,2}$ In general, a compound from this family is characterized by an angular tetracyclic framework that possesses a benz $[a]$ anthracene ring system. In the course of our screening program of rare actinomycetes in Thailand for novel bioactive secondary metabolites, fermentation of Saccharopolyspora sp. BIOTEC Culture Collection (BCC) 21906 led to the isolation of three new angucyclines saccharosporones A (1), B (2) and C (3), (Figure 1) and several known metabolites, including ochromycinone $(4),{ }^{3,4}(+)$-rubiginone $\mathrm{B}_{2}(5),{ }^{5}$ tetrangulol methyl ether $(6)^{6,7}$ and fujianmycin $\mathrm{A}^{8}$ In this paper, we report the isolation, structure elucidation and biological activities of these new angucyclinone polyketides.

The culture of Saccharopolyspora sp. BCC 21906 was extracted exhaustively with ethyl acetate. The crude substance was evaporated to dryness and fractionated by partition on the HP-20SS resin, subsequently eluted with acetone/water mixtures to obtain 20,30, 40, $50,60,70,80,90$ and $100 \%$ acetone fractions. Further purification of $70 \%$ and $80 \%$ acetone-water fractions by reversed-phase $\mathrm{C}_{18}$ HPLC furnished compounds $\mathbf{1}-\mathbf{3}$ as minor constituents.

\section{RESULTS AND DISCUSSION}

Saccharosporone A (1) was obtained as a yellowish powder and its molecular formula was established as $\mathrm{C}_{19} \mathrm{H}_{20} \mathrm{O}_{5}$ by high-resolution
HRESITOFMS $\left(\mathrm{m} / \mathrm{z}\right.$ 327.1231, $\left.[\mathrm{M}-\mathrm{H}]^{-}\right)$and its NMR data. The LRESIMS spectra showed ions corresponding to $[\mathrm{M}+\mathrm{Na}]^{+}$and $[\mathrm{M}+\mathrm{H}]^{+}$at $\mathrm{m} / \mathrm{z} 351$ and 329 , respectively. Analysis of the IR spectroscopic data showed an absorption band at $3474 \mathrm{~cm}^{-1}$, indicating hydroxyl functionality, and a signal at $1632 \mathrm{~cm}^{-1}$, which suggested the presence of a chelated quinone carbonyl group. ${ }^{9}$ The violet color reaction with the addition of sodium hydroxide indicated a peri-hydroxy quinone functional group.

The ${ }^{1} \mathrm{H}$ NMR spectrum of 1 , measured in acetone- $d_{6}$ (Table 1 ), illustrated three olefinic/aromatic proton signals at $\delta 7.26,7.58$ and 7.71, three hydroxy proton signals at $\delta 3.65,4.24$ and 12.14 , in addition to one methyl, three methine and four methylene proton signals. The analysis of ${ }^{1} \mathrm{H}-{ }^{1} \mathrm{H}$ COSY NMR spectrum showed three coupled spin systems. The first spin system consisted of three doublets of doublets at $\delta 7.267 .58$ and 7.71, which can be attributed to 1,2,3trisubstituted aromatic ring system. The second spin system involved a hydroxy $(\delta 4.24)$-bearing methine $(\delta 4.04)$ adjacent to a methylene group $(\delta$ 2.88-2.90). The final spin system had a methine $(\delta 2.77)$ connected to two correlated methylenes $(\delta 1.06,1.70$ and 1.92) attached to a methine at $\delta 2.29$ that also coupled to a methyl group $\left(\begin{array}{l}\delta \\ 0.89)\end{array}\right)$ and another methylene ( $\delta 1.38$ and 2.06).

The ${ }^{13} \mathrm{C}$ NMR/DEPT spectrum of 1 showed 19 carbon resonances of a methyl group ( $\delta 22.4), 2$ carbonyl carbons ( $\delta 183.5$ and 190.8), 3 non-oxygenated olefinic/aromatic methine carbons $(\delta 118.4,123.2$ and 136.2), 5 olefinic/aromatic quaternary carbons, including 1 bearing oxygen, 1 oxygenated quaternary carbon, 3 methines and 
4 methylene carbons. The major portion of the angucyclinone backbone could be assembled through the interpretation of COSY and HMBC correlations (Figure 2). The cross-peaks between H-9 $(\delta$ $7.26)$ and $\mathrm{H}-10(\delta 7.71)$ to $\mathrm{C}-8(\delta$ 161.1 $)$ suggested the presence of an oxygenated carbon in the aromatic ring. The ${ }^{1} \mathrm{H}$ NMR signal at $\delta$ 12.14 could be assigned to a chelated peri-hydroxy group attached to C-8 according to its $\mathrm{HMBC}$ correlations to the carbons at C-7a $(\delta$ 114.9), C-8 and C-9 ( $\delta$ 123.2). The aromatic methine at $\mathrm{H}-11$ $(\delta$ 7.58) correlated to carbonyl at C-12 $(\delta$ 183.5) indicated the carbonyl position adjacent to the trisubstituted aromatic ring. Both methine signal at $\mathrm{H}-12 \mathrm{~b}\left(\delta\right.$ 2.77) and methylene protons at $\mathrm{H}_{2}-6$ $(\delta$ 2.88-2.90) showed HMBC correlations to the same carbons at C-4a $(\delta 69.1)$, C-5 ( $\delta$ 72.7), C-6a $(\delta$ 141.1) and C-12a $(\delta 147.4)$, while $\mathrm{H}-12 \mathrm{~b}$ correlated to a carbonyl carbon at C-12 and H-6 to a carbonyl at C-7 ( $\delta$ 190.8), confirming the second spin system next to the
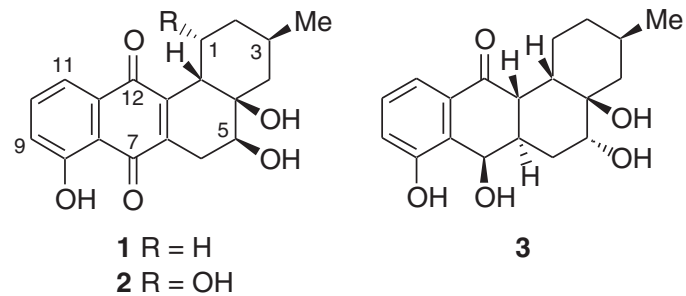

Figure 1 The structures of saccharosporones A (1), B (2) and C (3) from Saccharopolyspora sp. BCC 21906. quinone ring. The $\mathrm{HMBC}$ correlations from methine proton at $\mathrm{H}-5$ $(\delta$ 4.04) to carbons at C-4a, C-6a and C-12b $(\delta$ 42.3) and COSY correlations between $\delta 4.04$ and $\delta 4.24$ established a secondary alcohol at $\mathrm{C}-5$, whereas HMBC correlations from hydroxyl proton at $\delta 3.65$ to C-5 and C-12b supported the position of a tertiary alcohol at C-4a. Analysis of the COSY allowed the assignment of C-12b/C-1/C-2/C-3/ C-4 connectivities, which made up a major portion of the third spin system. In addition, methylene signals at $\mathrm{H}_{2}-4(\delta 1.38,2.06)$ showed correlations to carbons at C-4a, C-5 and C- $12 \mathrm{~b}$, while the other methylene at $\delta 1.92$ correlated to C-4a, C-12a and C-12b, establishing the core structure of the third spin system. Unlike the other angucyclinone polyketides, saccharosporone A lacked a carbonyl group at C-1 but instead contained a secondary alcohol at C-5 position.

An attempt to determine the absolute configuration of $\mathbf{1}$ was carried out using Mosher's method under several conditions but none of the derivatization reactions was successful, possibly because of the steric hindrance of secondary alcohol in the axial orientation. The relative stereochemistry of molecule 1 was determined by the interpretation of the NOESY NMR spectroscopic data. The strong NOESY correlations from methylene signal at $\mathrm{H}_{\mathrm{e}}-4(\delta$ 2.06) to methine protons at $\mathrm{H}-3(\delta$ 2.29) and $\mathrm{H}-5(\delta$ 4.04) suggested that these protons were on the same side of the ring. In addition, the important correlations between a methine proton $\mathrm{H}-12 \mathrm{~b}(\delta 2.77)$ and two methylene signals at $\mathrm{H}_{\mathrm{a}}-2(\delta 1.06)$ and $\mathrm{H}_{\mathrm{a}}-4(\delta 1.38)$, along with the fact that no correlation between $\mathrm{H}-5$ and $\mathrm{H}-12 \mathrm{~b}$ has been observed, confirmed that $\mathrm{H}-5$ and $\mathrm{H}-12 \mathrm{~b}$ were on the opposite side of the ring. The cis relative configuration of two hydroxyl groups at

Table $1{ }^{1} \mathrm{H}$ and ${ }^{13} \mathrm{C}$ NMR spectroscopic data $\left(500 \mathrm{MHz}\right.$, acetone- $\left.d_{6}\right)$ for saccharosporones A (1), B (2) and C (3)

\begin{tabular}{|c|c|c|c|c|c|c|}
\hline \multirow[b]{2}{*}{ Position } & \multicolumn{2}{|c|}{ Saccharosporone A (1) } & \multicolumn{2}{|c|}{ Saccharosporone B (2) } & \multicolumn{2}{|c|}{ Saccharosporone C (3) } \\
\hline & $\delta_{C}$, type & $\delta_{H}(J$ in $H z)$ & $\delta_{C}$, type & $\delta_{H}(J$ in $H z)$ & $\delta_{C}$, type & $\delta_{H}(J$ in $H z)$ \\
\hline 1 & $28.5, \mathrm{CH}_{2}$ & $1.92, \mathrm{~m}$ & $83.5, \mathrm{CH}$ & $4.25, d(5.3)$ & 22.6, $\mathrm{CH}_{2}$ & $\begin{array}{l}1.81, \text { qd }(12.7,3.3) \\
1.32, \text { dq }(12.7,3.5)\end{array}$ \\
\hline 2 & $34.6, \mathrm{CH}_{2}$ & $1.70, \mathrm{~m} \mathrm{1.06, \textrm {m }}$ & $39.5, \mathrm{CH}_{2}$ & $1.84, \mathrm{~m} 1.17, \mathrm{~m}$ & $34.9, \mathrm{CH}_{2}$ & $1.62-1.64, \mathrm{~m} \mathrm{0.88-0.90, \textrm {m }}$ \\
\hline 3 & $29.5, \mathrm{CH}$ & $2.29, \mathrm{~m}$ & $25.9, \mathrm{CH}$ & $2.12-2.14, \mathrm{~m}$ & $29.8, \mathrm{CH}$ & $2.33-2.35, \mathrm{~m}$ \\
\hline 3-Me & $22.4, \mathrm{CH}_{3}$ & $0.89, d(6.6)$ & $20.5, \mathrm{CH}_{3}$ & $1.02, \mathrm{~d}(6.4)$ & 22.7, $\mathrm{CH}_{3}$ & $0.83, \mathrm{~d}(6.6)$ \\
\hline $\begin{array}{l}4 \\
4 a\end{array}$ & $\begin{array}{l}49.8, \mathrm{CH}_{2} \\
69.1, \mathrm{C}\end{array}$ & $2.06, \mathrm{~m} \mathrm{1.38,t}$ (12.9) & $\begin{array}{l}45.4, \mathrm{CH}_{2} \\
73.7, \mathrm{C}\end{array}$ & $2.09-2.11, \mathrm{~m} \mathrm{1.64, \textrm {t } ( 1 2 . 5 )}$ & $\begin{array}{l}50.5, \mathrm{CH}_{2} \\
71.4, \mathrm{C}\end{array}$ & $2.00-2.02, \mathrm{~m} 1.19, \mathrm{t}(12.8)$ \\
\hline $4 \mathrm{a}-\mathrm{OH}$ & & $3.65, \mathrm{~s}$ & & $4.49, \mathrm{~s}$ & & $3.23, \mathrm{~s}$ \\
\hline $\begin{array}{l}5 \\
5-\mathrm{OH}\end{array}$ & $72.7, \mathrm{CH}$ & $\begin{array}{l}4.04, \mathrm{~m} \\
4.24, \text { br d }(3.1)\end{array}$ & 76.7, $\mathrm{CH}$ & $4.09, \mathrm{~m}$ & $75.5, \mathrm{CH}$ & $3.85, \mathrm{~m}$ \\
\hline 6 & $30.7, \mathrm{CH}_{2}$ & 2.88-2.90, m & $31.7, \mathrm{CH}_{2}$ & $\begin{array}{l}2.83, \text { dd }(19.1,1.8) \\
2.65, \text { dd }(19.1,3.3)\end{array}$ & $34.5, \mathrm{CH}_{2}$ & $\begin{array}{l}2.60, \mathrm{td}(13.2,2.7) \\
1.63, \mathrm{dt}(13.3,2.7)\end{array}$ \\
\hline $6 a$ & $141.1, \mathrm{C}$ & & $143.7, \mathrm{C}$ & & $32.4, \mathrm{CH}$ & 2.44, tt $(12.5,2.7)$ \\
\hline 7 & $190.8, \mathrm{C}$ & & $190.7, \mathrm{C}$ & & $62.8, \mathrm{CH}$ & $5.07, \mathrm{br} \mathrm{m}$ \\
\hline 7-OH & & & & & & 3.99, br m \\
\hline $7 a$ & $114.9, \mathrm{C}$ & & $115.4, \mathrm{C}$ & & $132.2, \mathrm{C}$ & \\
\hline 8 & $161.1, \mathrm{C}$ & & $161.2, \mathrm{C}$ & & $154.5, \mathrm{C}$ & \\
\hline $8-\mathrm{OH}$ & & $12.14, \mathrm{~s}$ & & $12.11, \mathrm{~s}$ & & \\
\hline 9 & $123.2, \mathrm{CH}$ & 7.26, dd $(8.4,1.0)$ & 123.6, $\mathrm{CH}$ & $7.28, \mathrm{dd}(8.4,1.0)$ & $119.7, \mathrm{CH}$ & $7.11, \mathrm{dd}(8.0,1.0)$ \\
\hline 10 & $136.2, \mathrm{CH}$ & $7.71, \mathrm{dd}(8.4,7.5)$ & $136.3, \mathrm{CH}$ & $7.73, \mathrm{dd}(8.4,7.5)$ & $128.4, \mathrm{CH}$ & $7.24, \mathrm{t}(7.8)$ \\
\hline 11 & $118.4, \mathrm{CH}$ & $7.58, \mathrm{dd}(7.5,1.0)$ & $118.5, \mathrm{CH}$ & $7.59, \mathrm{dd}(7.5,1.0)$ & $117.7, \mathrm{CH}$ & $7.46, d(7.7)$ \\
\hline $11 a$ & $132.8, \mathrm{C}$ & & $132.5, \mathrm{C}$ & & $133.7, \mathrm{C}$ & \\
\hline 12 & $183.5, \mathrm{C}$ & & 182.7, C & & $200.3, \mathrm{C}$ & \\
\hline $12 \mathrm{a}$ & $147.4, \mathrm{C}$ & & $145.8, \mathrm{C}$ & & $43.1, \mathrm{CH}$ & 3.37, dd $(12.5,4.5)$ \\
\hline $12 b$ & $42.3, \mathrm{CH}$ & $2.77, \mathrm{t}(8.8)$ & $46.8, \mathrm{CH}$ & 3.04, d (22.4) & 43.9, $\mathrm{CH}$ & $2.30, \mathrm{~m}$ \\
\hline
\end{tabular}




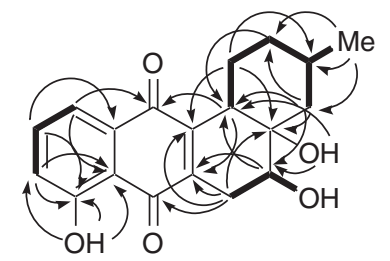

1

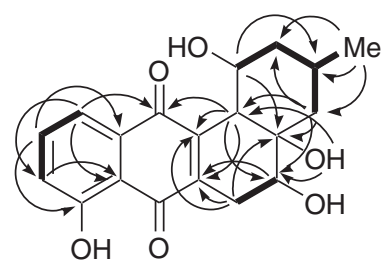

2

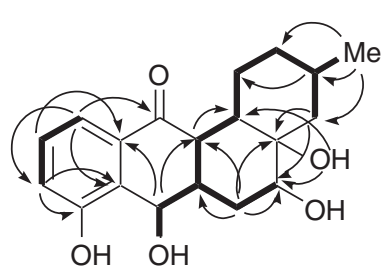

3

Figure 2 Selected COSY (bold lines) and HMBC (arrows) correlations observed for 1, $\mathbf{2}$ and $\mathbf{3}$.

C-4a and C- 5 could be proposed on the basis of the analysis by NOESY and 1D NOE difference spectrum. Irradiation of the methylene proton at $\mathrm{H}_{2}-1\left(\delta\right.$ 1.92) showed correlation to $\mathrm{H}_{2}-6(\delta$ 2.88-2.90), which supported this arrangement (Figure 3).

Saccharosporone B (2) was obtained as a yellowish powder and its structure was also elucidated on the basis of the interpretation of 2D NMR data. In comparison to 1 , both ${ }^{1} \mathrm{H}$ and ${ }^{13} \mathrm{C}$ NMR chemical shifts were quite comparable (Table 1$)$, except the major difference at C-1 $(\delta$ 83.5) attributed to oxygenated methine $(\delta 4.25)$ instead of a methylene group. The correlation patterns of the COSY and HMBC NMR spectral data were revealed to be very similar to $\mathbf{1}$ (Figure 2). The molecular formula of 2 was established as $\mathrm{C}_{19} \mathrm{H}_{20} \mathrm{O}_{6}$ by HRESITOFMS and only differed from 1 by having one additional hydroxy group instead. This conclusion was supported by its ${ }^{13} \mathrm{C}$ NMR chemical shift in the downfield region at C-1. Therefore, saccharosporone B (2) could be established as a 1-hydroxy analogue of $\mathbf{1}$. The relative configuration of 2 was also derived based on the interpretation of NOESY spectrum, and the same correlation pattern has been observed in comparison to 1 . The methine proton at $\mathrm{H}-12 \mathrm{~b}(\delta$ 3.04) showed correlations to the methylene signals at $\mathrm{H}_{\mathrm{a}}-2(\delta 1.17)$ and $\mathrm{H}_{\mathrm{a}}-4(\delta 1.64)$, while the oxygenated methine at $\mathrm{H}-5(\delta 4.09)$ correlated to the methylene proton $\mathrm{H}_{\mathrm{e}}-4(\delta 2.09-2.11)$ and a methine signal at $\mathrm{H}-3 \quad(\delta$ 2.12-2.14). Accordingly, the configuration of two hydroxy groups at C-4a $(\delta$ 73.7) and C-5 $(\delta 76.7)$ could be proposed to stay on the same ring side as similar to 1. The presence of a cross-peak between $\mathrm{H}-1$ ( $\delta$ 4.25) and H-12b, whereas no correlation between $\mathrm{H}-1$ and $\mathrm{H}_{\mathrm{a}}-3$ has been recorded, confirming that the additional secondary alcohol at $\mathrm{C}-1$ was on the opposite side of the ring when compared with the other two hydroxy groups at C-4a and C-5. Both $\mathbf{1}$ and 2 possessed similar relative configurations as well as their optical rotations that exhibited the same negative sign. The color reaction with sodium hydroxide from

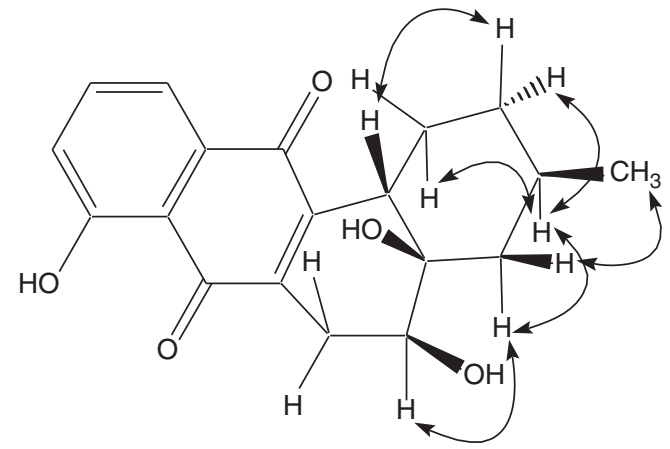

Figure 3 Assigned relative configuration of $\mathbf{1}$ from selected NOESY NMR correlations.

yellow to violet also supported the presence of a peri-hydroxy quinone functional group.

Compound 3, saccharosporone C, was also obtained as a yellowish powder and its structure was found to be closely related to compound 1. The ${ }^{1} \mathrm{H}$ and ${ }^{13} \mathrm{C}$ NMR spectra of $\mathbf{3}$ is mostly similar to $\mathbf{1}$ with the same 1,2,3-trisubstituted aromatic ring. The major difference is the change in the quinone ring, as only one carbonyl carbon remained at C-12 ( $\delta$ 200.3), whereas C-7 ( $\delta$ 62.8) has been altered to an oxygenated methine signal. Furthermore, two olefinic quaternary carbons, which formed the double bond between C-6a and C-12a, have been replaced with two aliphatic methine carbons. A molecular formula of $\mathrm{C}_{19} \mathrm{H}_{24} \mathrm{O}_{5}$ of 3 was established by HRESITOFMS $\left(\mathrm{m} / \mathrm{z}\right.$ 333.1697, $\left.[\mathrm{M}+\mathrm{H}]^{+}\right)$. Analysis of the COSY data allowed the assignment of the $\mathrm{C}-12 \mathrm{a} / \mathrm{C}-6 \mathrm{a} / \mathrm{C}-7 /$ hydroxyl group $\left(\begin{array}{ll}\delta & 3.99\end{array}\right)$ connectivities, and HMBC correlations from H-7 $(\delta$ 5.07) to C-11a $(\delta$ 133.7) and C-12a $(\delta 43.1)$ further confirmed that a carbonyl at C-7 in $\mathbf{1}$ and $\mathbf{2}$ has been replaced by a methine carbon attached to a hydroxy group, while the double bond between C-6a and C-12a became saturated. The relative configuration of $\mathbf{3}$ was proposed on the basis of NOESY spectrum and by analysis of vicinal coupling constants. The configurations at C-3, C-4a and C-12b were established to be similar to those of compound 1. Important correlation between $\mathrm{H}-6 \mathrm{a}(\delta 2.44)$ and $\mathrm{H}_{\mathrm{a}}-1(\delta 1.81)$ confirmed the assignment of configurations at C-4a and C-12b. The position of a hydroxyl group at C-5 was opposite to $\mathbf{1}$ and 2 as suggested by the lack of NOESY correlations from $\mathrm{H}-5$ to $\mathrm{H}-3$ and H-6a. The trans configuration at C-6a and C-12a was supported by NOESY correlations from a methine signal at $\mathrm{H}-6 \mathrm{a}$ to $\mathrm{H}_{\mathrm{a}}-1, \mathrm{H}_{\mathrm{e}}-6(\delta 1.63)$ and $\mathrm{H}-7$, along with correlations from $\mathrm{H}-12 \mathrm{a}\left(\begin{array}{ll}\delta & 3.37)\end{array}\right)$ to $\mathrm{H}_{\mathrm{a}}-6 \quad\left(\begin{array}{ll}\delta & 2.60\end{array}\right)$ and $\mathrm{H}-12 \mathrm{~b}\left(\begin{array}{ll}\delta & 2.30\end{array}\right)$. Furthermore, the large coupling constant between H-6a and H-12a $\left(J_{\mathrm{H}-6 \mathrm{a} / \mathrm{H}-12 \mathrm{a}}=12.5 \mathrm{~Hz}\right)$ represented a diaxial relationship of these protons. The relative configuration of the hydroxy at C-7 was confirmed by NOESY correlations from $\mathrm{H}-7$ to $\mathrm{H}_{\mathrm{e}}-6\left(\begin{array}{ll}\delta & 1.63)\end{array}\right)$ and H-6a and from the lack of correlation between H-7 and H-12a or $\mathrm{H}_{\mathrm{a}}-6$.

Isolated pure metabolites were screened for antimalarial, antibacterial, antifungal and cytotoxic activities. Compounds 1, 2, 5 and $\mathbf{6}$ exhibited antimalarial activities against Plasmodium falciparum $\mathrm{K} 1$ with respective $\mathrm{IC}_{50}$ values of $4.1,3.9,6.0$ and $4.6 \mu \mathrm{M}$, whereas 1, 2, 4 and 6 showed growth inhibition against Mycobacterium tuberculosis with $\mathrm{IC}_{50}$ values of $76.2,72.7,40.8$ and $19.7 \mu \mathrm{M}$, respectively. None of them exhibited activities against Bacillus cereus, while only 2 displayed antifungal activity against Candida albicans with an $\mathrm{IC}_{50}$ value of $46.2 \mu \mathrm{M}$. New angucyclinones 1 and 2 showed cytotoxic activities against all three cancer cell lines (KB, MCF-7 
Table 2 Cytotoxic activities of compounds 1-6 against Vero cell and various cancer cell lines

\begin{tabular}{lcccc}
\hline & Vero cells & $K B$ & MCF-7 & NCI-H187 \\
\cline { 2 - 5 } Compound & \multicolumn{4}{c}{ IC $_{50}(\mu \mathrm{M})$} \\
\hline $\mathbf{1}$ & 9.1 & 9.1 & 3.4 & 7.7 \\
$\mathbf{2}$ & 12.3 & 4.9 & 3.6 & 4.5 \\
$\mathbf{3}$ & Inactive & Inactive & Inactive & 41.5 \\
$\mathbf{4}$ & Inactive & Inactive & Inactive & 30.3 \\
$\mathbf{5}$ & Inactive & 49.8 & 51.3 & 14.7 \\
$\mathbf{6}$ & 25.7 & 26.5 & 16.9 & 5.5 \\
\hline
\end{tabular}

and NCI-H187) while 3 only exhibited weak cytotoxicity against NCI-H187 (Table 2).

\section{EXPERIMENTAL PROCEDURES}

\section{General}

Optical rotations were measured on a JASCO P-1030 digital polarimeter. UV spectra were obtained on a SPEKOL 1200 spectrophotometer (Analytikjena, Jena, Germany). FT-IR spectra were taken on a Bruker Alpha-E spectrometer (Bruker Optik, GmbH, Ettlingen, Germany). ${ }^{1} \mathrm{H},{ }^{13} \mathrm{C}$, DEPT, COSY, HMQC, HMBC and NOESY NMR spectra were recorded on a Bruker AV500D spectrometer (Bruker BioSpin AG Fällanden, Switzerland). ESI-TOF mass spectrometer measurements were obtained on a Micromass LCT (Micromass UK Limited, Manchester, UK) and a Bruker micrOTOF mass spectrometer (Bruker Daltonik GmbH, Bremen, Germany).

\section{Biological material}

The actinomycete Saccharopolyspora sp. (BCC 21906) was isolated from a soil collected at Evergreen forest, Khao Kitchakut National Park, Chanthaburi Province, Thailand. Analysis of the nucleotide sequence of the 16S rRNA gene of Saccharopolyspora sp. BCC 21906 exhibited a sequence similarity to the genes of S. antimicrobica I05-00074(T) (98.62\%) and S. hirsuta subsp. kobensis JCM 9109(T) (98.14\%). The collection and taxonomic identification were performed by Mr Chanwit Suriyachadkun (BIOTEC). A specimen has been deposited at BIOTEC Culture Collection and designated as BCC 21906.

\section{Culture conditions}

Saccharopolyspora sp. BCC 21906 was maintained on the International Streptomyces Project medium 2 at $28^{\circ} \mathrm{C}$ for $20-30$ days. Later, the agar was cut into pieces $\left(1 \times 1 \mathrm{~cm}^{2}\right)$ and inoculated into $3 \times 250 \mathrm{ml}$ Erlenmeyer flasks each containing $25 \mathrm{ml}$ of Bio 19.1 medium (glucose $20 \mathrm{~g}$, peptone $5 \mathrm{~g}$, yeast extract $2 \mathrm{~g}$, meat extract $5 \mathrm{~g}, \mathrm{NaCl} 0.5 \mathrm{~g}, \mathrm{CaCO}_{3} 3 \mathrm{~g}$ and vitamin $\mathrm{B}$ complex solution $1 \mathrm{ml}$, per 1 liter of distilled water). After the incubation on a rotary shaker $\left(250\right.$ r.p.m.) at $28^{\circ} \mathrm{C}$ for 7 days, each primary culture was transferred into a 1000-ml Erlenmeyer flask containing $250 \mathrm{ml}$ of the same liquid medium and incubated at $28^{\circ} \mathrm{C}$ for 7 days on a rotary shaker ( 250 r.p.m.). Each $25 \mathrm{ml}$ portion of the secondary cultures was transferred into $20 \times 1$ liter Erlenmeyer flasks each containing $225 \mathrm{ml}$ of production medium LS2 (mannitol $20 \mathrm{~g}$, soy meal $20 \mathrm{~g}$ and trace element mix $0.25 \mathrm{ml}$, per 1 liter of distilled water). The mixture of trace elements consisted of $(\mathrm{w} / \mathrm{v}): \mathrm{CaCl}_{2}, 0.4 \% ; \mathrm{ZnSO}_{4}, 0.2 \%$; $\mathrm{Na}_{2} \mathrm{~B}_{4} \mathrm{O}_{7}, 0.01 \% ; \mathrm{FeSO}_{4}, 0.5 \%$; KI, 0.005\%; $\mathrm{CoCl}_{2}, 0.05 \% ; \mathrm{CuSO}_{4}, 0.02 \%$; $\mathrm{MnCl}_{2}, 0.2 \% ; \mathrm{Na}_{2} \mathrm{MoO}_{4}, 0.005 \%$; (v/v) $\mathrm{H}_{2} \mathrm{SO}_{4}$ (95-97\% p.a.), $0.1 \%$. A total of $51(20 \times 250 \mathrm{ml})$ of BCC 21906 culture was incubated on rotary shakers (250 r.p.m.) for 7 days at $28^{\circ} \mathrm{C}$.

\section{Extraction and isolation}

The organic constituents from a 51 culture of Saccharopolyspora sp. strain BCC 21906 were extracted with ethyl acetate. The crude organic layer was concentrated in vacuo to yield a dark substance $(3.7 \mathrm{~g})$, which was partitioned by Diaion HP20SS (Supelco Bellefonte, PA, USA) column chromatography $\left(3.5 \times 25 \mathrm{~cm}^{2}\right.$, acetone:water) to yield nine fractions $(20,30,40,50,60,70,80$, 90 and $100 \%$ acetone mixtures). The fractions eluted with $70 \%$ and $80 \%$ acetone-water $(160 \mathrm{mg})$ were combined and subjected to further purification by gradient preparative HPLC using a reversed-phase column (Phenomenex Luna 10u C18(2) 100A (Phenomenex Torrance, CA, USA), $21.2 \times 250 \mathrm{~mm}^{2}$, $10 \mu \mathrm{m} ; 10 \mathrm{ml} \mathrm{min}{ }^{-1}, 45 \% \mathrm{MeCN} / \mathrm{H}_{2} \mathrm{O}$ over $10 \mathrm{~min}, 45-50 \% \mathrm{MeCN} / \mathrm{H}_{2} \mathrm{O}$ over $10 \mathrm{~min}, 50 \% \mathrm{MeCN} / \mathrm{H}_{2} \mathrm{O}$ over $10 \mathrm{~min}, 50-100 \% \mathrm{MeCN} / \mathrm{H}_{2} \mathrm{O}$ over $20 \mathrm{~min}$, $100 \% \mathrm{MeCN}$ over $20 \mathrm{~min})$ to afford compounds $1(9.7 \mathrm{mg}), 2(1.9 \mathrm{mg}), 3$ $(2.4 \mathrm{mg})$ and $5(12.9 \mathrm{mg})$. The $90 \%(183.2 \mathrm{mg})$ and $100 \%(57.7 \mathrm{mg})$ acetonewater fractions were also subjected to the purification by gradient HPLC (Phenomenex Luna $\mathrm{C}_{18}$ preparative, $10 \mathrm{ml} \mathrm{min}{ }^{-1}, 50 \% \mathrm{MeCN} / \mathrm{H}_{2} \mathrm{O}$ over $10 \mathrm{~min}, 50-60 \% \mathrm{MeCN} / \mathrm{H}_{2} \mathrm{O}$ over $10 \mathrm{~min}, 60 \% \mathrm{MeCN} / \mathrm{H}_{2} \mathrm{O}$ over $20 \mathrm{~min}$, $60-100 \% \mathrm{MeCN} / \mathrm{H}_{2} \mathrm{O}$ over $10 \mathrm{~min}, 100 \% \mathrm{MeCN}$ over $\left.20 \mathrm{~min}\right)$ to yield compounds 4 (35.1 mg), 5 (1.6 mg) and $\mathbf{6}(3.7 \mathrm{mg})$.

\section{Saccharosporone A (1)}

Yellow amorphous solid; $[\alpha]_{\mathrm{D}}-103.2(c \quad 0.3, \mathrm{MeOH}) ; \mathrm{UV}(\mathrm{MeOH}) \lambda_{\max }$ $(\log \varepsilon) 215 \mathrm{~nm}$ (4.05), $245 \mathrm{~nm}$ (3.87), $273 \mathrm{~nm} \mathrm{(3.91),} 421 \mathrm{~nm} \mathrm{(3.52);}$ IR $v_{\max }$ (ATR) 3474, 2947, 1632, 1611, 1455, 1284, 1237, $1065 \mathrm{~cm}^{-1}$; for NMR data, see Table 1; ESIMS $[\mathrm{M}+\mathrm{Na}]^{+} m / z$ 351; ESIMS $[\mathrm{M}+\mathrm{H}]^{+}$ $\mathrm{m} / \mathrm{z}$ 329; HRESITOFMS $[\mathrm{M}-\mathrm{H}]^{-} \mathrm{m} / \mathrm{z} 327.1231$ (calcd for $\mathrm{C}_{19} \mathrm{H}_{19} \mathrm{O}_{5}$, 327.1232).

\section{Saccharosporone B (2)}

Yellow amorphous solid; $[\alpha]_{\mathrm{D}}-87.3(c \quad 0.03, \mathrm{MeOH}) ; \mathrm{UV}(\mathrm{MeOH}) \lambda_{\max }$ (log ع) $215 \mathrm{~nm}$ (4.03), $245 \mathrm{~nm}$ (3.83), $273 \mathrm{~nm}$ (3.82), $421 \mathrm{~nm}$ (3.49); IR $v_{\max }$ (ATR) $3470,2925,1635,1612,1457,1288,1267,1243,1038 \mathrm{~cm}^{-1}$; for NMR data, see Table 1; ESIMS $\left[\mathrm{M}-\mathrm{H}_{2} \mathrm{O}+\mathrm{Na}\right]^{+} \mathrm{m} / z$ 349; HRESITOFMS [M $\left.\mathrm{H}_{2} \mathrm{O}+\mathrm{Na}\right]^{+} \mathrm{m} / z 349.1047$ (calcd for $\mathrm{C}_{19} \mathrm{H}_{18} \mathrm{O}_{5} \mathrm{Na}, 349.1052$ ).

\section{Saccharosporone C (3)}

Yellow amorphous solid; $[\alpha]_{\mathrm{D}}-20.1\left(c\right.$ 0.07, MeOH); UV (MeOH) $\lambda_{\max }$ ( $\log \varepsilon) 222 \mathrm{~nm}(4.10), 259 \mathrm{~nm}$ (3.93), $313 \mathrm{~nm}$ (3.48); IR $v_{\max }$ (ATR) 3402, 2952, 2923,1703,1665,1588,1291,1038 $\mathrm{cm}^{-1}$; for NMR data, see Table 1; ESIMS $[\mathrm{M}+\mathrm{Na}]^{+} \mathrm{m} / z$ 355; HRESITOFMS $[\mathrm{M}+\mathrm{H}]^{+} \mathrm{m} / z 333.1697(\mathrm{calcd}$ for $\mathrm{C}_{19} \mathrm{H}_{25} \mathrm{O}_{5}, 333.1702$ ).

\section{Biological assays}

Antimalarial activity against $P$. falciparum $\mathrm{K} 1$ was evaluated by the microculture radioisotope technique. ${ }^{10}$ The $\mathrm{IC}_{50}$ value of a standard antimalarial agent, dihydroartemisinin, was $0.001 \mu \mathrm{M}$. Antimicrobial assay against B. cereus was performed using the resazurin microplate technique. ${ }^{11}$ Vancomycin, used as a standard antibacterial drug, showed an MIC value of $0.69 \mu \mathrm{m}$. Growth inhibition against $M$. tuberculosis $\left(\mathrm{H}_{37} \mathrm{Ra}\right.$ strain) was determined by a green fluorescent protein microplate assay. ${ }^{12}$ The MIC value of a standard drug, isoniazid, was $0.69 \mu \mathrm{M}$. A green fluorescent protein-based assay ${ }^{13}$ was used to determine cytotoxicity against Vero cell (African green monkey kidney fibroblasts), while antifungal activity against $C$. albicans and cytotoxic tests against cancer cell lines, including KB (human epidermoid carcinoma), MCF-7 (human breast cancer) and NCI-H187 (human small cell lung cancer), were performed using the resazurin microplate assay. ${ }^{14}$ The standard antifungal agent, amphotericin $\mathrm{B}$, exhibited antifungal activity with an $\mathrm{IC}_{50}$ value of $0.13 \mu \mathrm{M}$, while ellipticine used as standard control for cyctotoxic assay against vero cell lines, displayed an $\mathrm{IC}_{50}$ value of $5.07 \mu \mathrm{M}$. Doxorubicin was used as positive controls for cytotoxic tests against KB, MCF-7 and NCI-H187 with respective $\mathrm{IC}_{50}$ values of $0.65,16.3$ and $0.1 \mu \mathrm{M}$. MIC and $\mathrm{IC}_{50}$ values $>50 \mu \mathrm{g} \mathrm{ml}^{-1}$ were reported as inactive.

\section{ACKNOWLEDGEMENTS}

We are very grateful to Bioresources Research Network (BRN) of the National Center for Genetic Engineering and Biotechnology (BIOTEC) for financial support. 
1 Krohn, K. \& Rohr, J. Angucyclines: total syntheses, new structures, and biosynthetic studies of an emerging new class of antibiotics. Top. Curr. Chem. 188, 127-195 (1997).

2 Rohr, J. \& Thiericke, R. Angucycline group antibiotics. Nat. Prod. Rep. 9, 103-137 (1992).

3 Bowie, J. H. \& Johnson, A. W. The structure of ochromycinone. Tetrahedron Lett. 8, 1449-1452 (1967).

4 Taniguchi, M. et al. YM-181741, a novel benz[a]anthraquinone antibiotic with antiHelicobacter pylori activity from Streptomyces sp. J. Antibiot. 55, 30-35 (2002).

5 Oka, M. et al. Chemical and biological properties of rubiginone, a complex of new antibiotics with vincristine-cytotoxicity potentiating activity. J. Antibiot. 43, 967-976 (1990).

6 Shigihara, Y. et al. 6-Deoxy-8-0-methylrabelomycin and 8-0-methylrabelomycin from a Streptomyces species. J. Antibiot. 41, 1260-1264 (1988).

7 Grabley, S. et al. Secondary metabolites by chemical screening. Part 19. SM 196 A and B, novel biologically active angucyclinones from Streptomyces sp. J. Antibiot. 44, 670-673 (1991).

8 Rickards, R. W. \& Wu, J. P. Fujianmycins $A$ and B, new benz[a]anthraquinone antibiotics from a Streptomyces species. J. Antibiot. 38, 513-515 (1985).
9 Pretsch, E., Simon, W., Seibl, J. \& Clerc, T. Tables of Spectral Data for Structure Determination of Organic Compounds. 2nd edn, 1130 (Springer, Berlin, Germany, 1989).

10 Desjardins, R. E., Canfield, C. J., Haynes, J. D. \& Chulay, J. D. Quantitative assessment of antimalarial activity in vitro by a semiautomated microdilution technique. Antimicrob. Agents Chemother. 16, 710-718 (1979).

11 Sarker, S. D., Nahar, L. \& Kumarasamy, Y. Microtitre plate-based antibacterial assay incorporating resazurin as an indicator of cell growth, and its application in the in vitro antibacterial screening of phytochemicals. Methods 42, 321-324 (2007).

12 Collins, L. A., Torrero, M. N. \& Franzblau, S. G. Green fluorescent protein reporter microplate assay for high-throughput screening of compounds against Mycobacterium tuberculosis. Antimicrob. Agents Chemother. 42, 344-347 (1998).

13 Changsen, C., Franzblau, S. G. \& Palittapongarnpim, P. Improved green fluorescent protein reporter gene-based microplate screening for antituberculosis compounds by utilizing an acetamidase promoter. Antimicrob. Agents Chemother. 47, 3682-3687 (2003).

14 O'Brien, J., Wilson, I., Orton, T. \& Pognan, F. Investigation of the Alamar Blue (resazurin) fluorescent dye for the assessment of mammalian cell cytotoxicity. Eur. $J$. Biochem. 267, 5421-5426 (2000).

Supplementary Information accompanies the paper on The Journal of Antibiotics website (http://www.nature.com/ja) 